\title{
International Monetary Cooperation and Democratic Institutions: The Importance of Executive-Legislative Relations in Germany and France, 1919-1929*
}

\author{
CHANSOO $\mathrm{CHO}^{* * *}$
}

\begin{abstract}
This article examines how changes in formal political institutions can affect the extent to which a nationally defined monetary policy is committed to an international monetary order by comparing the German and French cases during the period of 1919-1929. There is no dearth of studies that employ domestic political institutional variables to explain policy outcomes regarding international economic relations. And at the same time, for the past decade, a host of "second image reversed" works have improved our understanding of domestic-international interaction. While many scholars of international political economy have written about domestic sources of trade policy, increasing numbers of authors have devoted substantial attention to the explanatory power of domestic variables in monetary issues. Particularly, when accounting for variations on democratic commitment to international monetary cooperation, the importance of executivelegislative relations deserves special attention. Germany and France during the 1920s provide us with an interesting pair of comparison in that their parliamentary democracies had subtle differences in executive-legislative relations.
\end{abstract}

Keywords: international monetary cooperation, democratic institutions, executive-legislative relations, interwar years, Germany, France

\footnotetext{
${ }_{* *}^{*}$ Kangnam University supported this research through a 2005 Kangnam University Research Grant. *** Assistant Professor of International Studies at Kangnam University, San 6-2 Kugal-dong, Kiheung-gu, Yong-in, Kyunggi 446-702, Korea; Tel: 82-31-280-3826; E-mail: chansoocho@hanmail.net. The author wishes to thank T.V. Paul and ISR's two anonymous reviewers for their helpful comments and suggestions.
} 


\section{THE THEORETICAL PUZZLE}

I

nternational monetary cooperation has been among the policy agendas involving major industrial nations since the 1970s, especially the U.S. abandonment of the dollar-gold standard that was a pillar of the postwar international economic order. While the Bretton Woods system allowed participating countries to engage in controls on short-term capital movements, ${ }^{1}$ globalizing forces, after the closing of the gold window in 1971, have put pressure on national governments to shape monetary policy in close association with fluctuating external markets. U.S. hegemony when coupled with the politics of growth in advanced industrial democracies had rendered international monetary cooperation a virtual non-issue; it had been considered an implicit property of the postwar regime. ${ }^{2}$ Globalization and the subsequent opening up of national markets have made it almost impossible to take cooperation for granted largely because various domestic players came to be affected by the international flow of money.

Jeffry Frieden provides a useful framework with which one may be able to explain under what circumstances international monetary cooperation is rendered implicit or explicit by drawing on a distinction between closed and open economies. In a closed economy, cleavage over monetary policy runs between debtors and creditors both of whose focus is on the interest rate. In an open economy, the politics of monetary policy implicates tradables and nontradables sectors who are concerned with movements in the exchange rate. ${ }^{3}$ Although interest rates and exchange rates are closely intertwined with one another, international cooperation is taken more seriously in open economies because exchange rates are basically about the relation to other national currencies. Given their sensitivity to the value of other national currencies, domestic producer groups with varying degrees of trade dependence become major influences on the monetary policy process that affects the way cooperation among nations is shaped or arrested. In other words, domestic actors in an open economy are more directly involved in the politics of monetary policy, and thereby have higher stakes in the direction and content of international cooperation than their counterparts in a closed economy. Economic openness has the effect of making the issue of cooperation ${ }^{4}$ explicit among nations.

While useful in determining the extent to which international monetary cooperation becomes politicized domestically, Frieden's analytical scheme does not clearly show how to explain varying degrees of national government's commitment to international monetary order. Of course, it should not be a problem that the world is not composed of just two kinds of economies, open and closed, because Frieden is talking about ideal types, not about specific, empirical observations. A more refined model of international monetary cooperation should be able to explain why national economies with similar levels of openness respond to the issue of cooperation quite differently. Since open and closed economies 
represent ideal types of empirical reality, two or more open economies' different posturing to cooperation should not be explained just by scaling economic openness. I suggest to look into domestic political institutions as a way to account for variations on monetary policy taken by open economies.

This article examines how changes in formal political institutions can affect the extent to which a nationally defined monetary policy is committed to an international monetary order by comparing the German and French cases during the period of 1919-1929. There is no dearth of studies that employ domestic political institutional variables to explain policy outcomes regarding international economic relations. And at the same time, for the past decade, a host of "second image reversed" works have improved our understanding of domestic-international interaction. While many scholars of international political economy have written about domestic sources of trade policy, increasing numbers of authors have devoted substantial attention to the explanatory power of domestic variables in monetary issues. ${ }^{5}$ Particularly when accounting for variations on democratic commitment to international monetary cooperation, the importance of executive-legislative relations deserves special attention. Germany and France during the 1920 s provide us with an interesting pair of comparison in that their parliamentary democracies had subtle differences in executive-legislative relations.

The rest of the essay is organized as follows. Section II describes the historical puzzle that constitutes the empirical testing ground for an institutionalist model of international monetary cooperation. Section III surveys three main perspectives of international monetary cooperation during the 1920s. Section IV explains varying experiences of the German and French governments with postwar stabilization through the lens of executive-legislative relations. I conclude with a discussion on the advantages of combining social class and institutionalist explanations.

\section{THE HISTORICAL PUZZLE}

The decade after the end of World War I is marked by its transitory nature in the political as well as economic sense, especially in Europe and the United States. Economically, the time period showed earlier signs of stabilization, successive bouts of inflation (and the German hyperinflation), and later signs of restabilization in the postwar trading and monetary order that contrasted sharply with the upcoming Depression. The prewar system combining freer trade and the gold standard-which was established during the 1860 s and maintained until after the relative decline of the British hegemony began was never restored fully as a result of multiple factors including rampant economic nationalism. Politically, the 1920 s represented the latter part of what Samuel Huntington calls the "second wave of democratization," with a notable exception of Fascist Italy. 6 With the end of the war, most European countries experienced a revolutionary 
crisis triggered by the political and economic demands of lower classes whose collective power was strengthened through their mass participation in the war effort. Autocratic regimes gave way to more democratic ones, although in many countries of Eastern Europe traditional dictatorships were retained throughout the period.7 With the introduction of proportional representation system and the establishment of parliamentary sovereignty in major European countries, the 1920s saw a continent-wide political change towards mass democracy.

This realignment of political topography brought about the restructuring of the domestic economy in each country. Although restructuring took different forms in different countries, more similarities stood out. Unbridled forces of the market were discredited, and organized interests made claims to their "legitimate" shares within the economy. Governments and the entrepreneurial class in some countries reluctantly accepted part of the claims by engaging in some sort of corporatist tripartite bargaining. ${ }^{8}$ Even in countries that did not have structural and institutional foundations for corporatist intermediation, the heightened wave of mass politics rendered the management of the economy more accountable to voters' interests and preferences.

Social pressures placed on the economic policy process led to striking changes in foreign economic policy of major industrial countries. Unilateral devaluation and tariff protection were justified as contributing to the viability of the domestic economy and thereby consolidating a stable political order. But it is important here to note that countries responded to the collapse of the freer trade-gold standard system in different ways. Shift toward protection in trade was the common practice with the partial exception of Britain, which finally abandoned the practice of freer trade by establishing the Imperial Preference System in 1932. By contrast, more cross-national variations were observed in the extent to which currency depreciation was used as an economic weapon. Britain tried to retain its hegemony through the maintenance of the gold standard, while France also stuck to the gold standard despite its onerous war debts incurred to the United States.

Germany as a defeated country had to pay reparations to the victor nations, France and Britain, and the postwar burden was often cited as a source of political instability. In the early phase of postwar years, American money flowed into Germany for the purpose of reconstructing the production base. The then U.S. Secretary of Commerce, Herbert Hoover emphasized that American lending should be made for productive purposes, not for providing war-stricken people with short-term welfare. 9 This required the Germans to accept painful austerity measures in one way or another. One conventional way for the German government to take austerity measures was to raise taxes. The Social Democrats as the largest party within the Reichstag tried to follow the guideline of international capital, but could not implement any effective measures due to their weak hold on state and municipal as well as federal governments. The German government 
avoided adjustment to budget deficit and instead continued to pursue inflationary policies. This led to the vicious circle of hyperinflation and more foreign borrowings. The German failure to adhere to the rules of the international financial market discouraged the United States that was already timid in its support of European reconstruction and drove France into more aggressive and irresponsible policies against Germany such as the occupation of the Ruhr in 1923.

This brief sketch of international finance during the 1920 s should not be understood as a statement that Germany was most responsible for the vicious circle of war debts and reparations. Conflict over German reparations evolved not just between Germany and the Allied countries but also between France and Britain because the two countries differed in factor endowments that would have facilitated adjustment to a restored international economic regime. And in any event the United States considered the German reparations as a "purely European affair," while repayment on war debts was given as top priority. ${ }^{10}$ Indeed, the conundrum was a combined effect of the American insistence on the productive use of their money, the French government's provocative actions on the eastern border of Germany in the early postwar years, and the British "afterglow"11 despite its economic decline. To judge who ruined the liberal international economic subsystem during the 1920s is beyond the scope of this essay.

What should attract our attention instead is that the monetary responses of governments varied with the structures of democratic institutions and the patterns of political coalitions. Some countries had institutional arrangements and political coalitions more favorable to international monetary cooperation than others. Here, I tried to identify a causal relationship between democratic institutional arrangements and commitment to international monetary cooperation by looking into the cases of Germany and France. I hypothesized that an executive-centered government structure, when backed by a solid political coalition, is likely to be committed to international monetary cooperation. By testing this hypothesis in a comparison of Germany and France, I tried to secure a common ground on which to analyze other cases in terms of domestic institutional foundations of international monetary cooperation.

\section{EXPLANATORY MODELS OF INTERNATIONAL MONETARY COOPERATION DURING THE 1920s}

The central question this article addresses, why nations cooperate or not, has for the past two decades attracted the attention of scholars of international relations as a whole and international political economy in particular. And recent studies of compliance seem to overlap the larger literature of cooperation especially in their common emphasis on international institutions. ${ }^{12}$ Despite their remarkable achievements, many existing studies of international cooperation have been under- 
taken by examining a set of countries with similar political and economic systems. In doing so, those studies have come to share much with the literature on the democratic peace; democracies are likely to cooperate with each other, which in turn reduces the chances of going to war with each other. Although I agree that democratic states have institutional arrangements and economic interests more conducive to international cooperation than nondemocracies, we also should be able to explain under what circumstances democratic states fail to produce international cooperation. Two kinds of research strategy are possible to account for "within-democracy" differences in terms of international cooperation. An exogenous strategy is to employ independent variables other than regime type per se; and a list of factors would include war (both interstate and intrastate), revolution or revolutionary situation, economic recession, systemic distribution of power, etc. An endogenous strategy is to break down regime type into component parts such as electoral systems, party systems, power structure, etc.

The failure of the existing literature to do justice to policy divergence among similar political regimes derives from the tendency to treat a regime type as an undifferentiated whole. At least, all advanced industrial democracies are considered to be homogeneous in their stance toward international cooperation. Then, different responses of countries to international economic cooperation should be explained as an outcome of different economic structures and varying levels of productivity. But if two countries, as in the cases of Germany and France during the 1920s, do not differ from each other with respect to economic conditions, how can we explain the differences in policy outcomes? Of the two research strategies mentioned above, I chose the endogenous one that disaggregates a regime type into its constituent parts. Regime type, unlike the assumption of some existing studies of international relations, cannot be conceived as a monolithic entity. Instead, it must be understood as a composition of an array of formal and informal institutions which vary across countries.

These differences are reflected in the varying degree of regime responsiveness to the political and economic demands of its constituencies. Some democracies are more sensitive (and/or vulnerable) to societal pressures than others. And some democracies are more capable of pursuing a policy option that imposes a heavy burden on key producer groups within the society. Moreover, using this analytical framework allows us to account for a policy change within one regime. Democratic politics show a wider variation in the policy process and its outcomes than does nondemocratic rule because democratic regimes are subject to electoral cycles which make possible the alternation of elites in power on a regular basis. Depending on electoral outcomes and the resultant political coalitions, the nature of policy process can be greatly changed. These properties of democratic politics are more pronounced in the foreign economic policy process than other policy areas like national security. In this section the works that stress the impact of domestic institutional arrangements on international outcomes 
with special reference to the interwar experience are discussed.

\section{Eichengreen's Critique of Hegemonic Stability Theory}

The failure of countries to produce international monetary cooperation has been explained as the result of the lack of hegemonic leadership by many authors since Charles Kindleberger's seminal book, The World in Depression (1973) was published. In his book, Kindleberger suggested the core of what later Robert Keohane named hegemonic stability theory. He attributed the economic chaos, especially financial instability during the interwar period to the British inability and the American unwillingness to lead the international liberal economy. Kindleberger's keen suggestion was realistically refurbished by Stephen Krasner, historically and theoretically more refined by David Lake, and translated into institutionalism by Robert Keohane. ${ }^{13}$ Despite their different tones of argument, those authors seem to agree that a hegemon provides monetary stability by which other countries can engage in freer trade. That Britain in the nineteenth century played such a role was also accepted by them without any significant disagreement. More recently, however, hegemonic stability theory has been subject to criticism by many scholars. Among them the work of Barry Eichengreen stands out. ${ }^{14}$

First of all, he denies the conventional paired view that the pre-1914 gold standard was an outcome of British hegemony and that the interwar period was an exceptional case where hegemonic leadership was lacking. Instead, the prewar gold standard is viewed as a decentralized, multipolar system in which Paris and Berlin as well as London operated as centers of international finance. The interwar years are not an exception deviating from the common history of hegemonic leadership that in turn should be considered an exception. Rather, for Eichengreen, the period of 1945 to 1960 would be more exceptional in the sense that at that time U.S. hegemony was exercised without an active role on the part of other industrial nations of Western Europe and Japan. Eichengreen argues that the gold standard needed for its operation international cooperation as well as leadership. Moreover, his argument goes, in times of crisis like the interwar period international cooperation as opposed to leadership, was the key to a stable international monetary order.

Second, Eichengreen stresses the need to take into account domestic political factors when explaining international cooperation in bringing back the gold standard after the end of World War I. He takes note of the transition from elite politics to mass politics during the 1920s. The wave of democratic transition brought organized interests to the center of politics and increased the institutional links between them, and governments in turn led to the proliferation of veto points in the policy process. Corporatist strategy for securing labor peace and increasing productivity was adopted in various forms depending on each country's 
institutional legacies. Even in surplus countries, politicians and policymakers had to secure more fiscal reserves for domestic use. Thus, now capital flows were more subject to domestic political conditions than to the functional need for countercyclical measures. Capital flows from deficit countries to surplus ones became more and more politicized, which worked against the stabilization of the international monetary order.

When we consider Eichengreen's revising of financial history, hegemonic stability theory is flawed in explaining policy divergence among different countries and more importantly among different regimes. Indeed the theory is highly insensitive to the varying responses of countries other than a hegemon or a near-hegemon. While retaining some core assumptions of hegemonic stability theory, regime theorists have developed a useful analytical scheme that focuses on "a framework of norms expected to govern behavior." 15 It is not easy for any historically informed researcher to characterize the interwar monetary regime governing the countries of Europe and the United States either as a strong or as a weak regime. Unlike the prewar regime the restored gold standard faced different mixes of domestic-international interactions, which cannot be explained away simply by measuring the degree of hegemonic presence. That is why we need to understand what kinds of domestic factors were brought into play.

\section{Social Class Explanations}

Under the rubric of social class explanations can so many different approaches be grouped together. But within the literature on international economic cooperation social class explanations have usually paid attention to a correlation between political parties in power and their macroeconomic policies. The conventional wisdom was that parties of the left in power prefer and pursue policies aimed at full employment and more equal income distribution by taking the high price of inflation and deficit spending, while parties of the right in power place priority on price stabilization and the balanced budget to the detriment of low income groups' welfare. ${ }^{16}$ This policy divergence is projected into the foreign economic policy process as well. Whereas left-wing parties are concerned with promoting the welfare of constituencies at home by means of protection and capital control, the argument goes, right-wing parties are interested in adjusting the economy to the cycles of capital flows abroad through currency stabilization and freer trade.

Based narrowly on the experiences of some European countries where left parties were in power during the 1970s, the strength of left-wing political organizations and trade unions is viewed as working against trade liberalization and capital decontrol. ${ }^{17}$ But, as Beth Simmons' study has shown, 18 such a dichotomy does not fit in nicely with the historical evidence from the interwar period. During the 1920s the working class and its political organizations supported 
free trade, while resisting a high level of taxation. Conversely, the business community and right-wing parties wanted the continuance of protectionist policies that provided them with politically valuable rents. It should be noted, however, that trade politics and monetary politics are often in history on a collision course. Free traders do not necessarily endorse international monetary cooperation if the latter is expected to adversely affect their economic interests through fiscal conservatism. The interwar experience of the Weimar Republic well illustrates how trade politics and monetary politics diverged over the issues of taxation and reparations payments.

Thus, social class explanations should be modified so as to explain the composition of political coalitions within the polity. This kind of modification is necessary especially when considering the political status of most left-wing parties in interwar Europe that were far from the predominant (or hegemonic) force on their domestic front. While it is true that the German Sozialdemokratische Partei Deutschlands (SPD) and the Swedish Sveriges Arbetarparti (SAP) had become the most electorally successful parties in the two countries before World War I, social democracy in neither country was strong enough to form a majority government without seeking coalition partners. ${ }^{19}$ Moreover, during much of the 1920 s, specifically between late 1923 and mid-1928, the SPD was excluded from coalition governments at the national level, ${ }^{20}$ which does not accord with the argument that the left in power leads to fiscal laxity.

\section{Institutionalism}

The existing literature already has many good institutionalist accounts of international economic cooperation, but here I will focus on the works that deal with the problem of credibility. Helen Milner has explored under what institutional - mostly at the formal level - conditions government commit itself to international cooperation on issues such as trade liberalization. ${ }^{21}$ To identify domestic politics factors that are considered to affect policy outcomes, Milner employs three sets of analytical lenses: (1) executive-legislative relations, (2) power structure, i.e. presidentialism versus parliamentarism, and (3) the role of governmental administration structures. From her explanatory scheme can a hypothesis be derived that presidential government harnessed with executive prerogatives and a strong administrative machine is likely to engage in international cooperation in an institutionalized manner.

Such a hypothesis is based on an empirically plausible assumption that presidentialism is better than parliamentarism in making commitments to international cooperation credible just because a stronger form of executive politics is more likely in the former. Although there is ample evidence lending support to the argument, Milner's model of domestic sources of international cooperation is insensitive to the variations on democratic regimes and especially to with- 
in-parliamentarism differences in terms of commitments to international cooperation. Rather, many institutionalist authors in similar vein have focused on explaining different policy outcomes produced by different forms of executive-legislative relations in a presidential regime, especially the U.S. case. ${ }^{22}$ Divided government has long been a substitute for parliamentarism in implementing a theoretically robust test on as many cases as possible.

Lisa Martin provides a good antidote to this theoretical bias through a much wider comparison of the U.S. and western European cases on the role of national legislatures in making credible commitments to international cooperation. Martin rightly points to a tendency within the existing literature to underestimate the extent to which legislative influence is exercised on the policy process regarding international cooperation. She also notes that legislative influence tends to receive less attention than it deserves both theoretically and empirically when scholars try to observe domestic sources of international cooperation in parliamentary systems. ${ }^{23}$ Deeply influenced by a long-standing tradition that sees sharp differences between the American version of presidentialism and Europe's parliamentarism, many authors have assumed that a presidential government has more room for the executive's independent action on the international arena. As can be shown in the works of institutionalists, however, the nature of electoral systems and party systems also shape the patterns of executive-legislative relations and thereby produces variations among democracies as to international cooperation.

\section{EXPLAINING THE CASES OF GERMANY AND FRANCE, 1919-1929}

This section provides an institutionalist account of the German and French stances toward the issue of restoring stability to the post-World War I international monetary order by also drawing upon social coalition approaches to economic policy. Selecting two European countries, Germany and France, for comparison is useful to understand the role of executive-legislative relations in international monetary cooperation on at least two accounts.

First, Germany and France during the period under investigation had many things in common in terms of regime type. Both were a parliamentary regime in which "executive authority emerges from, and is responsible to, legislative authority." 24 This principle of parliamentary sovereignty means that in both countries the executive was structurally vulnerable to the legislative. But such institutional arrangements were often little more than constitutional trappings, not fully reflecting the actual balance of power within government. The Weimar constitution included the famous Article 48 granting the Reichspräsident to bring a government into office without active participation of the Parliament, to dissolve the Parliament without its consent and to issue decrees in states 
of emergency to restore public order. Notwithstanding such great prerogatives close to imperial power, the first president Friedrich Ebert could use his constitutional right for resolving economic matters only for a short time. ${ }^{25}$ In terms of the independence of cabinet in the policy process France ranked higher than Germany. Particularly, after Poincaré's return to power in 1926, Parliament granted him decree power to solve the currency crisis.

Second, Germany and France alike had weak governments in terms of its stability and durability. During the period under consideration, the Weimar Republic saw no government dominated by a political party with a stable majority within the Reichstag. There was no party that won over 50 percent of the vote during much of the republic's short life. Coalition government was more than a necessity; it was business as usual for Weimar political parties. The problem lay in the fact that coalition governments could not use executive power with any efficacy in coping with the pressures of reparations payment abroad and in determining where to spend foreign borrowings at home. In France, governments did not last more than six months on average. During the period of 1923 to 1927 alone a total of 12 cabinets were formed. As in Germany there was an alternation of power between the right and the left. When the Cartel des Gauches was in power, some signs of capital flight were clearly observed. Nonetheless, the French governments did not go off the gold standard and stuck to the principle of the strong franc, which weakens simplistic partisan arguments.

Taken together, Germany and France produced different policy outcomes despite their similarities in regime type and the durability of government. Both countries had the same payoff structure in which defection from the gold standard was a benefit-maximizing strategy. According to a purely cost-benefit calculus, currency depreciation and deficit spending should have been the norm. While Germany insisted on deficit spending through continued foreign borrowings, France raised taxes and at the same time made every effort to restore the value of the franc. One could say that the idea of exercising currency devaluation is shunned when respect for national prestige strongly exists. There is no need to deny that such consideration was a factor behind the French insistence on the strong franc. But concern for national prestige also prevented German conservatives and nationalists from accepting the ideas of international capital in favor of domestic austerity and liberal foreign economic policies.

This difference can be explained by looking into executive-legislative relations in the countries under consideration. During the 1920s the French policy process showed a clear move from parliamentary-centered structure to executive-centered one. This enabled the incumbent politicians and policymakers to push for unpopular and often painful orthodoxy measures with less intensive opposition from economic groups within the society. Politically the period represented the degeneration of the Third Republic into a government by decree. The strengthened executive 
was able to opt for defending the existing monetary order, which meant within the context of postwar mass politics facing greater resistance from society than had been the case during 1870-1914. Since the Banque de France had not functioned well as the central bank with a political independence of the degree assumed to be normal after 1945,26 a reinforced cabinet was necessary if it were to avoid the vicious circle of its ineffective German policy, the unavailability of American money, and the continuing weakening of the franc. It was Raymond Poincare that endorsed a highly aggressive form of executive authority to deal with the nation's financial impasse. In early January 1924 Poincare proposed the use of government by decree within a limit of six months especially to address the issues of fiscal soundness. Partly accepting the advices of British officials and U.S. financiers the Poincaré proposal included strong fiscal measures such as increasing all taxes by 20 percent. Other measures were also proposed only to provoke fierce opposition from left-wing parties and their constituencies because they were supposed to hard hit the popular classes. 27

When his policy package became subject to intense parliamentary battle for five weeks, Poincaré reasoned that legislative power could be restrained on a temporary basis in favor of more efficient economic policymaking. Poincaré's attempt to build a stronger executive met with opposition even from moderate Radical politicians like Édouard Herriot not just from leftists because government by decree was deemed to most Third Republic political forces incompatible with the principle of parliamentary sovereignty. Poincarés bill was eventually passed but was not followed by an enabling act, while Poincaré lost the 1924 election largely due to the increasing cost of the Ruhr occupation. ${ }^{28}$ When Poincaré returned to power in late July 1926 he enjoyed a much more solid base of support that came not just from his own center-right coalition and but also from the moderate left-wing politicians who shared the deep sense of financial crisis for the nation with the former leader of the Bloc National. Where the Briand-Caillaux government had failed to pass an enabling act for Poincaré's bill of 1924, the returned prime minister could secure an institutional foundation for government by decree through which his government was expected to "without time limit" defend the value of the franc in spite of negative impact on trade. 29

Political forces in Weimar Germany during the decade were struggling to take advantage of the newly instituted democratic constitution in their political fighting along preindustrial cleavage lines. Policy process was dictated by the logic of competition within parliament rather than reflecting the conflicts within the society and the economy. Although they were well aware of the need for austerity measures, Weimar politicians were reluctant to formulate and implement stabilization policies that would alienate their constituencies. Germany remained a fragmented parliamentary regime, and what Giovanni Sartori called "polarized pluralism" allowed political parties to act irresponsibly 30 Any policy options 
of international cooperation incurring domestic cost was viewed a remote possibility.

Private investors were disappointed with Germany's weak commitment to debt service by means of taxation. Only two percent of public spending was used for debt service, while the figure for Britain was close to 25 percent. The German government used nearly 60 percent of government spending to provide social services that had steadily expanded since the Wilhelmine era. That was a great increase as compared with the prewar level of 37 percent. 31 Welfare dependence among the ordinary Germans intensified in no small measure due to the centralization of federal governance under the Weimar constitution. Matthias Erzberger's financial reforms of 1919 gave the federal government the sole right to collecting most taxes including the income tax, while leaving state and municipal governments little sources of revenue. The problem lay in the fact that subnational governments still had responsibility for providing welfare programs and social services to their constituencies. Particularly city governments during the 1920 s were dominated by local business leaders, civic leaders, and the Social Democrats who despite many disagreements among themselves shared commitment to a Sozialstaat. Demographic change in the aftermath of the war was also a factor pushing municipal governments in larger cities to seek financial resources to cope with mounting welfare and social service demands. Frustrated with the reduced sources of funding, municipal governments turned to foreign capital that found attractive the German cities' "debt free" situation brought about by inflation. 32 This means that Germany externalized the costs of reparations payment by spending most of foreign borrowings to enhance the stability of fragmented political system, and by avoiding any tax increases.

Institutional factors by nature are likely to be formal rather than informal. Formal institutions are substantiated in the polity in the forms of constitutions, statutes, ordinances, etc. But at the same time they reflect the conflicts and distribution of interests within society and the economy. Executive-legislative relations are shaped by and transformed in tune with the distribution of power among social and political forces.

In Germany, the new republican constitution was written in the spirit of compromise between the Social Democrats and the center-right parties. The latter included a large group of conservative elites with a strong hold on the domestic economy. Moreover, throughout the life span of the Weimar Republic no single party could gain more than 50 percent of the vote due to the electoral system based on the principle of proportional representation. A corollary of this was the lack of a stable majority to pursue a coherent policy mix in foreign economic policy in favor of international monetary cooperation. The reshuffle of cabinet was so frequent that political parties were concerned about winning the game of domestic politics rather than about coping with international pressures in a cooperative way. Thus there was no effort to delegate legislative powers 
regarding economic matters to the cabinet.

The French case clearly shows the importance of the connection between formal institutions and political coalitions. France had a parliamentary regime based on an electoral system with a significant difference from that of Germany. It was a mixed system of majority and proportional representation. This made easier the formation of a stable majority and strengthened the government in power. One important factor accounting for the relative stability of the French parliamentary regime was the dominant role of the Radicals. The party was an indispensable partner for coalition government and had the strong support of farmers, one of the most influential social groups in the country since the founding of the Third Republic. Although the reshuffle of cabinet was as frequent as in Germany, the centrality of the Radicals gave continuity to France's foreign economic policy whose priority was on the stabilization of the franc. Protected by tariffs, the farmers did not resist the adherence to the gold standard.

\section{CONCLUSIONS ON RESEARCH STRATEGY}

The major theoretical concern of this paper was with examining how the variations of democratic institutions affect the foreign economic policy process. Democracy is far from a monolithic regime type into which national variations on electoral system and constitutional structure are collapsed. More importantly, democratic institutions vary from one government to another within a polity. Particularly, executive-legislative relations are plausibly expected to vary with the nature of policy process. While trade policy is subject to the shifting forces of mass democracy, monetary policy is relatively insulated from such political pressures because of its highly complicated, technical nature. 33 Recent institutionalist authors have produced good works on the politics of monetary policy by focusing on the variations on electoral systems, party systems, the central bank's political independence, etc. Despite the remarkable achievements made by institutionalists, monetary policy remains the realm of formal institutions rather than informal ones especially when compared to trade policy. 34 Trade policy is conceived as "the outcome of a process influenced by voters," 35 and the causal connection is more explicit and easier to identify than when we make the same analytical effort on monetary policy. A minority of voters may have some kind of opinion about monetary policy and may wish to push it into the policy process, but there is a problem of mobilization to be resolved. Monetary policy issues are not as amenable to political mobilization as trade policy issues.

I have no intention to disprove the conventional wisdom about the different nature of trade and monetary policy in relation to mass democracy. Instead here I have attempted to show that monetary policy is by its very nature affected by the way in which the executive deals with the legislative in formulating 
and implementing it. Mass political influences matter only to the extent that organized interests are well represented within a given party system. My research strategy here is based on Helen Milner's and Daniel Verdier's models. From Milner I have borrowed her points about the executive-legislative relations. She suggested a possible correlation between the concentration of executive power and more credible commitment to international cooperation. From Verdier I have borrowed his emphasis on the support base of the policy process. By doing this I intended to show that executive-legislative relations are translated into actual policies through the mediation of political coalitions. What made possible the delegation to the executive in France after 1926 was a stable political coalition around the Radicals. In contrast, Germany could not utilize its presidential power due to the fragmentary nature of political coalitions.

This kind of study may shed fresh light on the foreign economic policy process in both theoretical and historical terms. Theoretically this research benefits from and contributes to the existing literature on domestic sources of international cooperation. The existing literature, however, seems to be dominated by either institutionalism or game-theoretical models at the expense of social class explanations and other non-institutional factors. ${ }^{36}$ As has been shown in the section dealing with rival explanations, liberal institutionalism needs to be complemented by drawing on more of social class explanations. Rather than reducing institutions to social classes, I have tried to bring to the fore a more complex interrelationship among political coalitions, institutions, and policy process.

Historically, as Simmons pointed out, implications of the interwar years for international relations theory and foreign policy are derived from the fact that unlike the post-World War II period the interwar years were closer to a pluralistic, multipolar system than a bipolar one. ${ }^{37}$ After the end of the Cold War, many authors with starkly different policy prescriptions in mind have speculated that the world political economy would be becoming more and more similar to the situation of the interwar period. 38 In the absence of hegemonic leadership international financial community is increasingly decentralized and works in a destabilizing way. Financial instability at the systemic level did and does imply much larger room for the domestic politics of monetary policy to be played out. This essay should serve as a reminder that protagonists in the drama of monetary politics include farmers, workers, and veterans as well as central bankers, international financiers, and politicians.

\section{REFERENCES}

Alvarez, R. Michael, Geoffrey Garrett, and Peter Lange. 1991. Government Partisanship, Labor Organization, and Macroeconomic Performance. American Political Science Review 85(2): 539-56. 
Barber, William J. 1985. From New Era to New Deal: Herbert Hoover, the Economists, and American Economic Policy, 1921-1933. New York: Cambridge University Press.

Berman, Sheri. 1998. The Social Democratic Moment: Ideas and Politics in the Making of Interwar Europe. Cambridge, Mass.: Harvard University Press.

Bernhard, William and David Leblang. 1999. Democratic Institutions and Exchange-Rate Commitments. International Organization 53(1): 71-97.

Brawley, Mark R. 1999. Afterglow or Adjustment? Domestic Institutions and Responses to Overstretch. New York: Columbia University Press.

Broz, Lawrence J. 1997. The Domestic Politics of International Monetary Order: The Gold Standard. In Contested Social Orders and International Politics, ed. David Skidmore, pp. 53-91. Nashville, Tenn.: Vanderbilt University Press.

Carstairs, Andrew McLaren. 1980. A Short History of Electoral Systems in Western Europe. London: George Allen \& Unwin.

Castles, Francis G., ed. 1982. The Impact of Parties: Politics and Policies in Democratic Capitalist States. Beverly Hills, Calif.: Sage.

Chayes, Abram and Antonia Handler Chayes. 1993. On Compliance. International Organization 47: 175-205.

Clark, William Roberts and Mark Hallerberg. 2000. Mobile Capital, Domestic Institutions, and Electorally Induced Monetary and Fiscal Policy. American Political Science Review 94(2): 323-46.

Eichengreen, Barry. 1992. Golden Fetters: The Gold Standard and the Great Depression, 1919-1939. New York: Oxford University Press.

. 1996. Globalizing Capital: A History of the International Monetary System. Princeton, N.J.: Princeton University Press.

Frieden, Jeffry A. 1996. Economic Integration and the Politics of Monetary Policy in the United States. In Internationalization and Domestic Politics, ed. Robert O. Keohane and Helen V. Milner, pp. 108--36. New York: Cambridge University Press.

Garrett, Geoffrey and Peter Lange. 1989. Government Partisanship and Economic Performance: When and How does "Who Governs" Matter? Journal of Politics 51(3): 676-93.

Gowa, Joanne. 1988. Public Goods and Political Institutions: Trade and Monetary Policy Processes in the United States. International Organization 42(1): 15-32. Grieco, Joseph M. 1988. Anarchy and the Limits of Cooperation: A Realist Critique of the Newest Liberal Institutionalism. International Organization 42 (3): 485-507.

Helleiner, Eric. 1994. States and the Reemergence of Global Finance: From Bretton Woods to the 1990s. Ithaca, N.Y.: Cornell University Press.

Hibbs, Douglas A. 1977. Political Parties and Macroeconomic Policy. American Political Science Review 71(4): 1467-87.

Huntington, Samuel P. 1993. Democracy's Third Wave. In The Global Resurgence 
of Democracy, ed. Larry Diamond and Marc F. Plattner. Baltimore, Md.: Johns Hopkins University Press.

Keohane, Robert O. 1984. After Hegemony: Cooperation and Discord in the World Political Economy. Princeton, N.J.: Princeton University Press.

Kirchheimer, Otto. 1969. Decree Powers and Constitutional Law in France under the Third Republic. In Politics, Law, and Social Change: Selected Essays of Otto Kirchbeimer, ed. Frederic S. Burin and Kurt L. Shell. New York: Columbia University Press.

Kooker, Judith L. 1976. French Financial Diplomacy: The Interwar Years. In Balance of Power or Hegemony: The Interwar Monetary System, ed. Benjamin M. Rowland. New York: New York University Press.

Krasner, Stephen D. 1976. State Power and the Structure of International Trade. World Politics 28(3): 317-47.

Lake, David A. 1983. International Economic Structures and American Foreign Economic Policy, 1887-1934. World Politics 35(4): 517-43.

Lepsius, M. Rainer. 1978. From Fragmented Party Democracy to Government by Emergency Decree and National Socialist Takeover: Germany. In The Breakdown of Democratic Regimes: Europe, ed. Juan J. Linz and Alfred Stepan Baltimore. Md.: Johns Hopkins University Press.

Lijphart, Arend. 1984. Democracies: Patterns of Majoritarian and Consensus Governments in Twenty-One Countries. New Haven, Conn.: Yale University Press.

Luebbert, Gregory M. 1991. Liberalism, Fascism, or Social Democracy: Social Classes and the Political Origins of Regimes in Interwar Europe. New York: Oxford University Press.

McNeil, William C. 1986. American Money and the Weimar Republic: Economics and Politics on the Eve of the Great Depression. New York: Columbia University Press.

Maier, Charles S. 1975. Recasting Bourgeois Europe: Stabilization in France, Germany, and Italy in the Decade after World War I. Princeton, N.J.: Princeton University Press.

Martin, Lisa L. 1992. Coercive Cooperation: Explaining Multilateral Economic Sanctions. Princeton, N.J.: Princeton University Press.

. 2000. Democratic Commitments: Legislatures and International Cooperation. Princeton, N.J.: Princeton University Press.

Milner, Helen V. 1993. Maintaining International Commitments in Trade Policy. in Do Institutions Matter? Government Capabilities in the United States and Abroad, eds. R. K. Weaver and Bert A. Rockman. Washington, D.C.: The Brookings Institution.

1997. Interests, Institutions, and Information: Domestic Politics and International Relations. Princeton, N.J.: Princeton University Press.

O'Halloran, Sharyn. 1994. Politics, Process, and American Trade Policy. Ann Arbor, Mich.: University of Michigan Press. 
Oye, Kenneth A. 1992. Economic Discrimination and Political Exchange: World Political Economy in the 1930s and 1980s. Princeton, N.J.: Princeton University Press. Pauly, Louis W. 1995. Capital Mobility, State Autonomy and Political Legitimacy. Journal of International Affairs 48(2): 369-88.

Rogowski, Ronald. 1989. Commerce and Coalitions: How Trade Affects Domestic Political Alignments. Princeton, N.J.: Princeton University Press.

Sartori, Giovanni. 1966. European Political Parties: The Case of Polarized Pluralism. In Political Parties and Political Development, eds. Joseph LaPalombara and Myron Weiner. Princeton, N.J.: Princeton University Press.

Simmons, Beth A. 1993. Why Innovate? Founding the Bank for International Settlements. World Politics 45(3): 361-405. - 1994. Who Adjusts? Domestic Sources of Foreign Economic Policy During the Interwar Years. Princeton, N.J.: Princeton University Press. . 1998. Compliance with International Agreements. Annual Review of Political Science 1(1): 75-93.

Stein, Arthur A. 1990. Why Nations Cooperate: Circumstances and Choice in International Relations. Ithaca, N.Y.: Cornell University Press.

Verdier, Daniel. 1994. Democracy and International Trade: Britain, France, and the United States, 1860-1990. Princeton, N.J.: Princeton University Press.

Wallerstein, Michael. 1987. Unemployment, Collective Bargaining, and the Demand for Protection. American Journal of Political Science 31(4): 729-52. Webb, Michale C. 1995. The Political Economy of Policy Coordination: International Adjustment since 1945. Ithaca, N.Y.: Cornell University Press.

\section{ENDNOTES}

${ }^{1}$ Eric Helleiner. 1994. States and the Reemergence of Global Finance: From Bretton Woods to the 1990 s (Ithaca, N.Y.: Cornell University Press), p. 25.

2 In that regard, Michael Webb argues that "the extent of policy coordination in the Bretton Woods years has commonly been exaggerated, whereas since the 1970 s it has commonly been underestimated." Webb. 1995. The Political Economy of Policy Coordination: International Adjustment since 1945 (Ithaca, N.Y.: Cornell University Press), pp. ix-x.

3 Jeffry A. Frieden. 1996. Economic Integration and the Politics of Monetary Policy in the United States. In Robert O. Keohane and Helen V. Milner, eds., Internationalization and Domestic Politics (New York: Cambridge University Press), pp. 108-14.

4 As a number of scholars have already done, here I follow Robert Keohane's definition of cooperation as the mutual adjustment of actors to the actual or anticipated preferences of others. Keohane. 1984. After Hegemony: Cooperation and Discord in the World Political Economy (Princeton, N.J.: Princeton University Press), pp. 49-52.

5 For example, see Lawrence J. Broz. 1997. The Domestic Politics of International Monetary Order: The Gold Standard. in David Skidmore, ed., Contested Social Orders and International Politics (Nashville, Tenn.: Vanderbilt University Press), pp. 53-91; William Roberts Clark and Mark Hallerberg. 2000. Mobile Capital, Domestic Institutions, and Electorally Induced Monetary and Fiscal Policy. American Political Science Reviewv 94(2): 323-46; William Bernhard and David Leblang. 1999. Democratic Institutions and Exchange-Rate Commitments. International Organization 53(1): 71-97.

${ }^{6}$ Samuel P. Huntington. 1993. Democracy's Third Wave. In Larry Diamond and Marc F. Plattner, eds., The Global Resurgence of Democracy (Baltimore, Md.: Johns Hopkins University Press), p. 3. I intentionally use "Fascist" as opposed to "fascist" in order to distinguish Mussolini's polity during 
the 1920 s from the continent-wide fascist movements that led to a genuinely new political-economic regime in many countries including Germany.

${ }^{7}$ Gregory M. Luebbert. 1991. Liberalism, Fascism, or Social Democracy: Social Classes and the Political Origins of Regimes in Interwar Europe (New York: Oxford University Press).

8 Charles S. Maier. 1975. Recasting Bourgeois Europe: Stabilization in France, Germany, and Italy in the Decade after World War I (Princeton, N.J.: Princeton University Press).

9 William J. Barber. 1985. From New Era to New Deal: Herbert Hoover, the Economists, and American Economic Policy, 1921-1933 (Cambridge: Cambridge University Press), pp. 35-36.

${ }^{10}$ Judith L. Kooker. 1976. French Financial Diplomacy: The Interwar Years. In Benjamin M. Rowland, ed., Balance of Power or Hegemony: The Interwar Monetary System (New York: New York University Press), p. 94.

${ }^{11}$ For a discussion of afterglow efforts, see Mark R. Brawley. 1999. Afterglow or Adjustment? Domestic Institutions and Responses to Overstretch (New York: Columbia University Press), pp. 68-75.

${ }^{12}$ Keohane, After Hegemony; Joseph M. Grieco. 1988. Anarchy and the Limits of Cooperation: A Realist Critique of the Newest Liberal Institutionalism. International Organization 42(3): 485-507; Arthur A. Stein. 1990. Why Nations Cooperate: Circumstances and Choice in International Relations (Ithaca, N.Y.: Cornell University Press); Lisa L. Martin. 1992. Coercive Cooperation: Explaining Multilateral Economic Sanctions (Princeton, N.J.: Princeton University Press); Abram Chayes and Antonia Handler Chayes. 1993. On Compliance. International Organization 47: 175-205; Beth A. Simmons. 1998. Compliance with International Agreements. Annual Review of Political Science 1: 75-93.

${ }^{13}$ Stephen D. Krasner. 1976. State Power and the Structure of International Trade. World Politics, 28(3): 317-47; David A. Lake. July 1983. International Economic Structures and American Foreign Economic Policy, 1887-1934. World Politics 35(4): 517-43; Keohane, After Hegemony.

${ }^{14}$ Barry Eichengreen. 1992. Golden Fetters: The Gold Standard and the Great Depression, 1919-1939 (New York: Oxford University Press); 1996. Globalizing Capital: A History of the International Monetary System (Princeton, N.J.: Princeton University Press).

${ }^{15}$ Louis W. Pauly. Winter 1995. Capital Mobility, State Autonomy and Political Legitimacy. Journal 6 of International Affairs 48(2): 370-71, fn. 6.

${ }^{6}$ See Douglas A. Hibbs. 1977. Political Parties and Macroeconomic Policy. American Political Science Review 71(4): 1467-87; Francis G. Castles, ed. 1982. The Impact of Parties: Politics and Policies in Democratic Capitalist States (Beverly Hills, Calif.: Sage); Geoffrey Garrett and Peter Lange. 1989. Government Partisanship and Economic Performance: When and How does "Who Governs" Matter? Joumal of Politics 51(3): 676-93; R. Michael Alvarez, Geoffrey Garrett, and Peter Lange. 1991. Government Partisanship, Labor Organization, and Macroeconomic Performance. American Political Science Review 85(2): 539-56.

${ }^{17}$ Michael Wallerstein. 1987. Unemployment, Collective Bargaining, and the Demand for Protection. American Journal of Political Science 31(4): 729-52.

${ }^{18}$ Beth A. Simmons. 1994. Who Adjusts? Domestic Sources of Foreign Economic Policy During the Interwar Years (Princeton, N.J.: Princeton University Press).

${ }^{19}$ Sheri Berman. 1998. The Social Democratic Moment: Ideas and Politics in the Making of Interwar Europe (Cambridge, Mass.: Harvard University Press), pp. 5-6.

${ }^{20}$ Ronald Rogowski. 1989. Commerce and Coalitions: How Trade Affects Domestic Political Alignments (Princeton, N.J.: Princeton University Press), p. 79.

${ }^{21}$ Helen V. Milner. 1993. Maintaining International Commitments in Trade Policy. In R. K. Weaver and Bert A. Rockman, eds., Do Institutions Matter? Government Capabilities in the United States and Abroad (Washington, D.C.: The Brookings Institution), pp. 345-69; Milner, H.V. 1997. Interests, Institutions, and Information: Domestic Politics and International Relations (Princeton, N.J.: Princeton University Press).

${ }^{22}$ Sharyn O'Halloran. 1994. Politics, Process, and American Trade Policy (Ann Arbor, Mich.: University of Michigan Press).

${ }^{23}$ Lisa L. Martin. 2000. Democratic Commitments: Legislatures and International Cooperation (Princeton, N.J.: Princeton University Press), p. 1.

${ }^{24}$ Arend Lijphart. 1984. Democracies: Patterns of Majoritarian and Consensus Governments in Twenty-One Countries (New Haven, Conn.: Yale University Press), p. 68.

${ }^{25}$ M. Rainer Lepsius. 1978. From Fragmented Party Democracy to Government by Emergency Decree and National Socialist Takeover: Germany. In The Breakdown of Democratic Regimes: Europe, eds. Juan ${ }_{6} \mathrm{~J}$. Linz and Alfred Stepan (Baltimore, Md.: Johns Hopkins University Press), p. 47.

${ }^{26}$ During the 1920 s the Banque often resorted to "fresh money" that led to inflation and to eroded credibility of itself. Simmons, Who Adjusts? pp. 152-53.

${ }_{28}^{27}$ Ibid., p. 150 .

${ }^{28}$ Otto Kirchheimer. 1969. Decree Powers and Constitutional Law in France under the Third Republic. in Frederic S. Burin and Kurt L. Shell, eds., Politics, Law, and Social Change: Selected Essays of Otto Kircbbeimer (New York: Columbia University Press), pp. 111-12. 
${ }^{29}$ Simmons, Who Adjusts? p. 164; Kirchheimer, "Decree Powers and Constitutional Law," p. 112.

${ }^{30}$ Giovanni Sartori. 1966. European Political Parties: The Case of Polarized Pluralism. In Joseph LaPalombara and Myron Weiner, eds., Political Parties and Political Development (Princeton, N.J.: Princeton University Press), pp. 153-55; Andrew McLaren Carstairs. 1980. A Short History of Electoral Systems in Western Europe (London: George Allen \& Unwin), p. 165.

${ }^{31}$ Beth A. Simmons. 1993. Why Innovate? Founding the Bank for International Settlements. World Politics 45: 374 .

${ }^{32}$ William C. McNeil. 1986. American Money and the Weimar Republic: Economics and Politics on the Eve of the Great Depression (New York: Columbia University Press), pp. 7-9.

33 Joanne Gowa. 1988. Public Goods and Political Institutions: Trade and Monetary Policy Processes in the United States. International Organization 42(1): 15-32.

${ }^{34}$ Distinction between formal and informal institutions is not as clear as the terms show, but here the emphasis is placed on the degree to which societal interests and preferences are permeable to each category of institutions.

${ }^{35}$ Daniel Verdier. 1994. Democracy and International Trade: Britain, France, and the United States, 1860-1990 (Princeton, N.J.: Princeton University Press), p. xv.

${ }^{36}$ It should be noted that important variants exist within institutionalism that stress the role of ideas in the foreign economic policy process. See, for example, Judith Goldstein and Robert O. Keohane, eds. 1993. Ideas and Foreign Policy: Beliefs, Institutions, and Political Change (Ithaca, N.Y.: Cornell University Press).

${ }^{37}$ Simmons, "Why Innovate?" p. 363.

${ }^{38}$ One notable exception is Kenneth A. Oye. 1992. Economic Discrimination and Political Exchange: World Political Economy in the 1930s and 1980s (Princeton, N.J.: Princeton University Press) that warns of the danger of historical analogy that often ignores different policy environments. 